\title{
Antioxidant Properties of Human Colostrum
}

\author{
E. S. BUESCHER AND S. M. MCILHERAN \\ Department of Pediatrics and the Program in Infectious Diseases and Clinical Microbiology, University of Texas \\ Medical School at Houston, Houston, Texas 77030
}

\begin{abstract}
Because it has recently been hypothesized that human milk is antiinflammatory, the effects of aqueous human colostrum on human polymorphonuclear leukocyte (PMN) respiratory burst activity and selected enzymatic activities was examined. Aqueous colostrum was found to spontaneously reduce ferricytochrome $C$ in a concentration-dependent manner, prohibiting use of the standard assay to measure superoxide production. It also caused a significant concentration-dependent prolongation of the lagtime from stimulation of PMN with phorbol myristate acetate to the appearance of hydrogen peroxide. Substitution of an enzymatic peroxide-generating system for PMN did not alter the effect of colostrum. Colostrum also suppressed myeloperoxidase activity and lysozyme activity, but not $\beta$-glucuronidase activity in PMN lysates. Inclusion of colostrum in an in vitro assay of PMNmediated cell detachment significantly suppressed this PMN-mediated effect. These data demonstrate that aqueous human colostrum significantly interferes with PMN oxygen metabolic and enzymatic activities that are important in the mediation of acute inflammation. (Pediatr Res 24: 14-19, 1988)
\end{abstract}

\section{Abbreviations}

PMN, polymorphonuclear leukocytes

PMA, phorbol myristate acetate

$\mathrm{H}_{2} \mathrm{O}_{2}$, hydrogen peroxide

HBSS, Hanks' balanced salt solution without $\mathrm{Ca}^{++}, \mathrm{Mg}^{++}$, and phenol red

The PMN is the acute inflammatory cell of the body, and as such, performs two important roles: microbial killing and propagation/modulation of acute inflammation (1). Proper performance of these roles is dependent on an intact capability to generate oxygen metabolites via the respiratory burst $(2,3)$. Although the presence of large numbers of PMN in a physiologic fluid other than blood is usually taken as evidence of acute inflammation, human colostrum contains approximately $2 \times 10^{6} \mathrm{PMN} / \mathrm{ml}(4)$ without evidence of acute inflammation in the breast. The PMN present in colostrum are hypofunctional compared to blood PMN, having decreased oxygen metabolism and bactericidal activity (4) as well as depressed chemotactic responsiveness (5). To examine whether the hypofunction of colostral PMN and the lack of acute inflammation in the newly lactating breast might reflect inherent "antiinflammatory" characteristics of human colostrum, we tested the in vitro effects of colostrum on PMN oxygen metabolism at two levels: oxygen metabolite production by the PMN and oxygen metabolite-mediated cellular injury.

Received August 3, 1987; accepted February 25, 1988

Correspondence and reprints E. S. Buescher, University of Texas Medical School at Houston, 6431 Fannin, Room 1.741, Houston, TX 77030.

Supported through a grant from the Department of Pediatrics, University of Texas Medical School at Houston and NICHHD Grant HD 13021-09.

\section{METHODS}

Colostrum specimens. Samples of human colostrum were collected by breast pump from mothers 1 to 4 days postpartum. The colostrum was kept on ice until separated by centrifugation $\left(4^{\circ} \mathrm{C}, 81,000 \times g, 30 \mathrm{~min}\right)$. The time from colostrum collection to separation was typically $30-60 \mathrm{~min}$. After centrifugation, the aqueous fraction of the separated colostrum was harvested by puncturing the centrifuge tube above the cell pellet with a needle and pumping the aqueous fraction out at $2-4 \mathrm{ml} / \mathrm{min}$ using a peristaltic pump. Aqueous colostrum was stored in aliquots at $-70^{\circ} \mathrm{C}$ until studied; all studies used either fresh aqueous colostrum (never frozen) or aqueous colostrum thawed once. For experiments that used whole, acellular colostrum, fresh colostrum was centrifuged at $300 \times g$ for $10 \mathrm{~min}$ at $4^{\circ} \mathrm{C}$, the cream layer and aqueous phase decanted, remixed, and then used or frozen in aliquots at $-70^{\circ} \mathrm{C}$ until used.

$P M N$ studies. PMN were purified from heparinized human blood as described (6). PMN oxygen consumption was measured with a Clark oxygen electrode (7) using PMA, $20 \mathrm{ng} / \mathrm{ml}$ final concentration, as the stimulus. In these experiments, PMN were used at $2.5 \times 10^{6}$ cells $/ \mathrm{ml}$. PMA-stimulated neutrophil hydrogen peroxide production was measured by following horseradish peroxidase mediated oxidation of scopoletin by $\mathrm{H}_{2} \mathrm{O}_{2}$ (8). In these experiments, PMN were used at $10^{6}$ cells $/ \mathrm{ml}$

For studies examining the effects of aqueous colostrum on PMN enzyme activities, a lysate of purified PMN (approximately $10^{7} / \mathrm{ml}$ ) was used as the source for the enzymes myeloperoxidase, $\beta$-glucuronidase, and lysozyme. Separate aliquots of aqueous colostrum and PMN lysate were assayed for each enzyme. The sum of the enzyme activity in colostrum plus the activity in the PMN lysate activity (referred to as the "predicted" activity) was then compared to the activity of identical colostrum and PMN lysate aliquots first mixed together and then assayed (referred to as the "observed" activity). Pairs of predicted and observed values were then plotted against one another, and the regression line through the points was compared to a line with a slope of 1 by $t$ test. Myeloperoxidase activity of PMN lysates was measured using $O$-dianisidine as the chromagen (9). Specifically, triplicate 50- $\mu$ l samples (either PMN lysate $+\mathrm{H}_{2} \mathrm{O}$ colostrum $+\mathrm{H}_{2} \mathrm{O}$, or colostrum + lysate) were combined with $200 \mu \mathrm{l}$ of MPO buffer (made by combining $6 \mathrm{ml}$ of $\mathrm{HBSS}$ with $\mathrm{Ca}^{++}$and $\mathrm{Mg}^{++}$without phenol red, containing $1 \%$ bovine serum albumin, with $5 \mathrm{ml}$ of $0.1 \mathrm{M}$ phosphate buffer, $\mathrm{pH} 7.2$, with $1 \mathrm{ml}$ of $1.25 \mathrm{mg} / \mathrm{ml}$. $O$ dianisidine in water with $1 \mathrm{ml}$ of $0.05 \% \mathrm{H}_{2} \mathrm{O}_{2}$ in water) and incubated in 96-well microtiter plates for $15 \mathrm{~min}$ at room temperature. After $15 \mathrm{~min}$, color formation was read immediately (at $460 \mathrm{~nm}$ ) on an automated ELISA plate reader. Triplicate determinations were then averaged, and compared as described above. Lysozyme and $\beta$-glucuronidase activities were measured by standard methods $(10,11)$.

The effects of stimulated PMN on HEp-2 cell adherence were studied as follows. HEp-2 cells [a continuous cell line originally derived from a human epidermoid carcinoma (12) and frequently used to examine interactions between pathogenic enteric bacteria 
and epithelial cells $(13,14)]$ were grown to monolayers in 24well tissue culture plates using RPMI 1640 media with $10 \%$ fetal calf serum, $2 \mathrm{mM}$ glutamine, $50 \mu \mathrm{g} / \mathrm{ml}$ streptomycin, and $50 \mu \mathrm{g} /$ $\mathrm{ml}$ penicillin added. Monolayers were washed twice with HBSS, and $5 \times 10^{6}$ purified PMN were added to quadruplicate wells (approximately 10 PMN: $1 \mathrm{HEp}-2$ cell). PMA $(20 \mathrm{ng} / \mathrm{ml}$ final concentration), whole, acellular colostrum (10\% final concentration), and HBSS were added, and the cell cultures were incubated for $2 \mathrm{~h}$ at $37^{\circ} \mathrm{C}$. After $2 \mathrm{~h}$ the quadruplicate wells were washed twice with HBSS, the cells remaining were solubilized in $6 \mathrm{~N}$ $\mathrm{NaOH}$, and the total protein content of each well was determined (15) and the quadruplicates were averaged.

Cytochrome $C$ reduction. One part aqueous colostrum or diluted aqueous colostrum was mixed with 1 part ferricytochrome $\mathrm{C}(1.78 \mathrm{mg} / \mathrm{ml})$ and kept at room temperature for 10 min. Ferricytochrome $\mathrm{C}$ reduction was then quantitated by measuring the $\mathrm{OD}_{549}$ of each sample and comparing it to a blank that substituted water for the aqueous colostrum.

Acellular production of hydrogen peroxide. In some experiments, an acellular $\mathrm{H}_{2} \mathrm{O}_{2}$-generating system was substituted for purified PMN. In these experiments, a stock glucose solution (1 M) was used to bring the final glucose concentration to $10 \mathrm{mM}$, and glucose oxidase, $0.25 \mathrm{U}$, was added. At $35^{\circ} \mathrm{C}$, pH 5.1, this system produces $250 \mathrm{nmol}$ of $\mathrm{H}_{2} \mathrm{O}_{2} / \mathrm{min}$; under the assay conditions used (room temperature, $\mathrm{pH} 7$ ), this system produces $65.19 \pm 5.76 \mathrm{nmol} \mathrm{H}_{2} \mathrm{O}_{2} / \mathrm{min}$.

Calculation of colostral reducing activity. Cytochrome C-reducing activity of colostrum was calculated by a standard method (16) and is expressed in $\mathrm{nmol} / \mathrm{ml} . \mathrm{H}_{2} \mathrm{O}_{2}$-depleting activity was calculated by multiplying the lag time (in $\mathrm{min}$ ) by the final rate of $\mathrm{H}_{2} \mathrm{O}_{2}$ production (in $\mathrm{nmol} / \mathrm{min}$ ), divided by the volume of colostrum added.

Electrophoretic concentration of colostrum. Aliquots of aqueous colostrum were diluted 2- to 4-fold with $0.001 \mathrm{M}$ phosphate buffer, $\mathrm{pH} 8$. They were then concentrated using an electrophoretic concentrator (ISCO, Lincoln, NB) with $3.5-\mathrm{kDa}$ dialysis membranes at either end of the concentration cuvette. This device uses an electric field to concentrate charged molecules at the surface of a dialysis membrane with defined mol. wt. exclusion characteristics (17). The charge of the targeted molecule is controlled by the $\mathrm{pH}$ of the dilution buffer used. Dilution buffer of $\mathrm{pH} 8$ was used to dilute the colostrum based on preliminary experiments examining both the electrophoretic mobility and the pH stability of the colostrum activities. Concentration was performed for $2 \mathrm{~W}$ hours per cuvette at $4^{\circ} \mathrm{C}$.

Data shown are the mean \pm SEM; unless otherwise noted, statistical significance was determined by paired sample $t$ test whenever natural pairing occurred; otherwise, Student's $t$ test was used.

\section{RESULTS}

Effects of aqueous colostrum on PMN oxygen metabolism and enzymes. Initial experiments performed to examine whether aqueous colostrum had an effect on PMN superoxide production demonstrated that aqueous colostrum reduced ferricytochrome $\mathrm{C}$ spontaneously (Fig. 1). The degree of ferricytochrome $\mathrm{C}$ reduction was dependent on the amount of colostrum added; time course experiments showed that ferricytochrome $\mathrm{C}$ reduction began immediately on mixture, and was complete by $10 \mathrm{~min}$ at room temperature. Spontaneous reduction of cytochrome $\mathrm{C}$ was not affected by the presence of superoxide dismutase $(75 \mathrm{U} / \mathrm{ml})$. In comparison, the antioxidants; methionine $(1 \mathrm{mM})$, mannitol $(50 \mathrm{mM})$, and dimethylsulfoxide $(280 \mathrm{mM})$ did not spontaneously cause ferricytochrome $\mathrm{C}$ reduction. Aqueous colostrum was also found to spontaneously reduce $0.1 \%$ nitroblue tetrazolium (data not shown). The ferricytochrome $\mathrm{C}$ reducing capacity of aqueous colostrum was calculated to be $497 \pm 47 \mathrm{nmol} / \mathrm{ml}(n$ $=17)$. Boiling $\left(10 \mathrm{~min}\right.$ at $\left.100^{\circ} \mathrm{C}\right)$ resulted in retention of $96 \pm$ $11 \%$ of this activity $(n=4)$.
Because PMN superoxide production could not be assessed in the presence of aqueous colostrum, PMA-stimulated hydrogen peroxide production by PMN was examined. Aqueous colostrum caused a dose-dependent prolongation of the lagtime from PMA addition to scopoletin oxidation $\left(\mathrm{H}_{2} \mathrm{O}_{2}\right.$ production) (Fig. 2, left). This increase in the lag time was not due to delay in the onset of the respiratory burst, as aqueous colostrum had no effect on the time of onset of PMA stimulated oxygen consumption (Fig. 2, right). The effect of $10 \%$ aqueous colostrum on the rate of $\mathrm{H}_{2} \mathrm{O}_{2}$

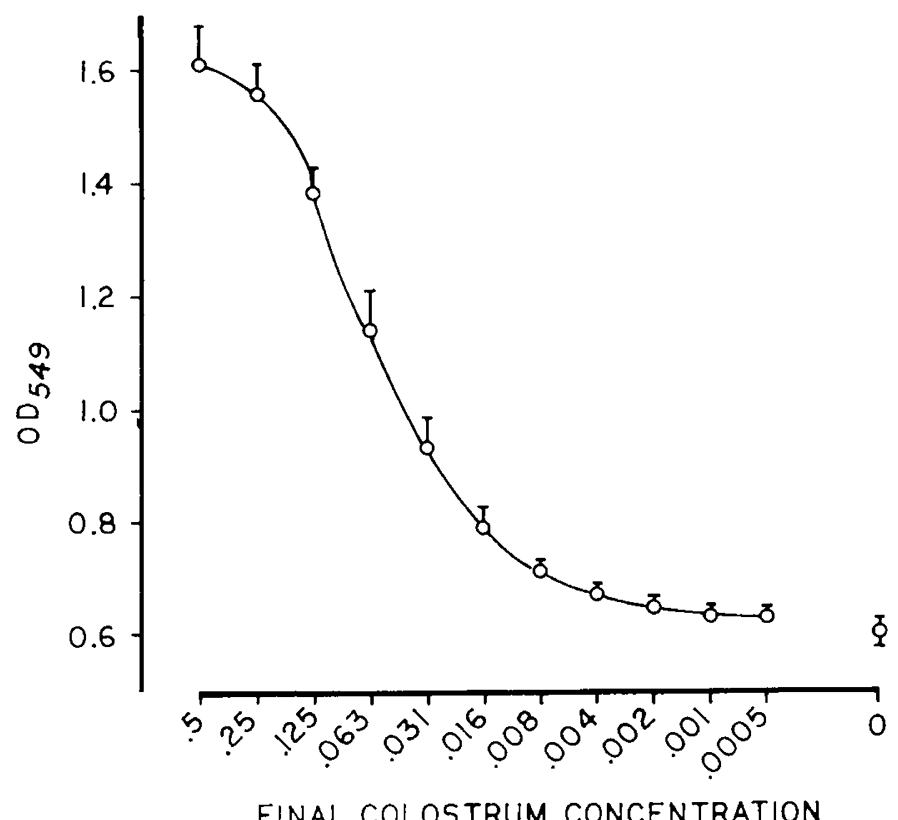

Fig. 1. Effects of combining cytochrome $\mathrm{C}$ and aqueous human colostrum. The ordinate shows OD549, absorption maximum for ferrocytochrome $\mathrm{C}$. The abscissa shows final aqueous colostrum concentration in assay.
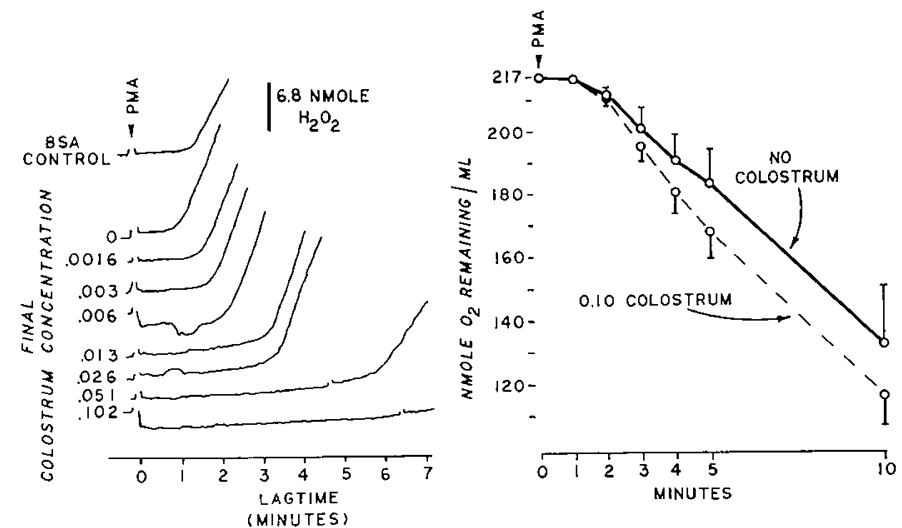

Fig. 2. Left, patterns of $\mathrm{H}_{2} \mathrm{O}_{2}$ production by human $\mathrm{PMN}$ in the presence of various concentrations of aqueous colostrum. The final aqueous colostrum concentrations are shown. A bovine serum albumin stock solution $(17 \mathrm{mg} / \mathrm{ml})$ was used as a control for protein content. The upper tracing shows a 0.10 final concentration of this stock. The lag time (in min) is shown on the abscissa. The arrow denotes time of cell stimulation with PMA ( $20 \mathrm{ng} / \mathrm{ml}$ final). The bar shows 10 fluorescence units, equal to the production of $6.8 \mathrm{nmol}$ of $\mathrm{H}_{2} \mathrm{O}_{2}$. The tracings show scopoletin fluorescence: upward deflection denotes loss of fluorescence due to oxidation by $\mathrm{H}_{2} \mathrm{O}_{2}$. Right, PMA-stimulated PMN oxygen consumption in the presence and absence of aqueous colostrum. The nmol of oxygen remaining are shown on the ordinate. Time in min is shown on the abscissa. The arrow denotes time of stimulation with PMA. Data points are mean \pm SEM. $n=5$ for no colostrum; $n=8$ for 0.10 colostrum. 
production by PMN could not be evaluated because of the prolonged lagtimes it caused. Lagtime prolongation was still seen in the presence of $2.5 \%$ colostrum, and at that concentration, the rate of $\mathrm{PMN} \mathrm{H}_{2} \mathrm{O}_{2}$ production was not significantly different than control $\left(15.98 \pm 2.17\right.$ versus $15.08 \pm 2.39 \mathrm{nmol} \mathrm{H}_{2} \mathrm{O}_{2} / \mathrm{min} /$ $2.5 \times 10^{6} \mathrm{PMN}$, control versus $2.5 \%$ colostrum, $n=7$ ).

Aqueous colostrum had no effect on PMN $\beta$-glucuronidase activity, assessed by comparing the activity of the enzyme in the absence (Fig. 3, predicted), and presence (Fig. 3, observed) of aqueous colostrum. In the presence of $50 \%$ aqueous colostrum, $\beta$-glucuronidase activity was $105.8 \pm 7.0 \%$ of control. Aqueous colostrum significantly depressed both PMN myeloperoxidase and lysozyme activities (Fig. 3, middle and bottom); $49.3 \pm 5.9 \%$
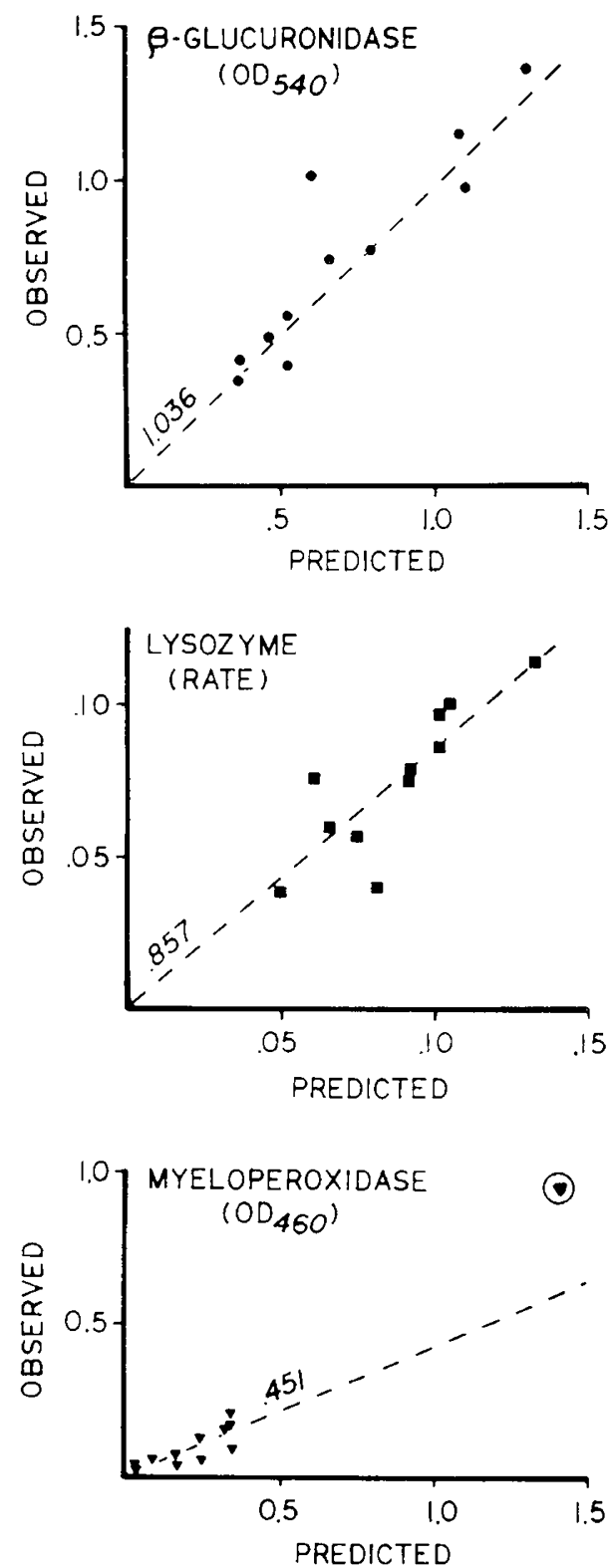

Fig. 3. The effects of aqueous colostrum on $\beta$-glucuronidase, lysozyme, and myeloperoxidase activities from human PMN lysates. The ordinates show observed values (activity of combined PMN lysate and colostrum). Abscissa shows predicted values (activities of PMN lysate and colostrum measured individually, then added). Dashed lines show regression slope for the data with intercept fixed at 0 . Numbers above dotted lines are the numerical slopes. The circled point in the lower panel is an experimental value excluded from the regression calculation because it is an outlier. of predicted myeloperoxidase activity $(p<0.001$ versus predicted) and $86.0 \pm 5.4 \%$ of predicted lysozyme activity $(p<0.01$ versus predicted) was observed in the presence of $50 \%$ aqueous colostrum.

Effects of aqueous colostrum on PMN-mediated HEp-2 cell detachment. As summarized in Table 1, HEp2 cells in tissue culture were not detached from the tissue culture substrate by purified PMN, by aqueous colostrum, by PMN with colostrum or by PMA alone. However, in the presence of PMN-stimulated by PMA, $42.0 \pm 6.2 \%$ of starting cellular protein remained after $2 \mathrm{~h}$. Addition of aqueous colostrum (10\%) to this condition partially abrogated the effect of the stimulated PMN, increasing the fraction of starting cellular protein to $73.3 \pm 8.5 \%$ after $2 \mathrm{~h}$ $(p<0.001$, without colostrum versus with colostrum, paired sample $t$ test).

Effects of aqueous colostrum on an acellular $\mathrm{H}_{2} \mathrm{O}_{2}$-producing system. To simplify examination of the effects of aqueous colostrum on $\mathrm{PMN} \mathrm{H}_{2} \mathrm{O}_{2}$ production, an enzymatic $\mathrm{H}_{2} \mathrm{O}_{2}$-producing system was substituted for PMN in further experiments. In the presence of excess glucose, glucose oxidase produces $\mathrm{H}_{2} \mathrm{O}_{2}$ at a constant rate, which is dependent on the glucose oxidase concentration. Aqueous colostrum delayed onset of scopoletin oxidation by this $\mathrm{H}_{2} \mathrm{O}_{2}$ producing system in a dose-dependent fashion, similar to its effect on PMN produced $\mathrm{H}_{2} \mathrm{O}_{2}$ (Fig. 4). The $\mathrm{H}_{2} \mathrm{O}_{2}$ depleting activity of colostrum, using this cell-free system, was $918 \pm 54 \mathrm{nmol} / \mathrm{ml}(n=18)$. Boiling $\left(10 \mathrm{~min}\right.$ at $\left.100^{\circ} \mathrm{C}\right)$ resulted in retention of $51 \pm 11 \%$ of activity $(n=6)$. In an additional experiment, the effects of high concentrations of colostrum on

Table 1. Effects of colostrum on PMN-mediated HEp2 cell detachment

$\begin{array}{lrrr} & \multicolumn{3}{c}{\begin{array}{c}\text { \% of total protein } \\ \text { remaining }\end{array}} \\$\cline { 3 - 4 } \multicolumn{1}{c}{\text {$Condition }$} & $\left.(n) & \text { Mean } & \text { SEM } \\ \hline \text { HEp2 cells alone } & 10 & 100 & \\ \text { HEp2 cells + PMN } & 9 & 96.54 & 3.85 \\ \text { HEp2 cells + colostrum } & 9 & 108.89 & 7.78 \\ \text { HEp2 cells + PMN + colostrum } & 4 & 87.88 & 7.39 \\ \text { HEp2 cells + PMA (20 ng/ml) } & 4 & 103.50 & 5.60 \\ \text { HEp2 cells + PMA + PMN } & 10 & 41.99 & 6.24 \\ \text { HEp2 cells + PMA + PMN + } & 10 & 73.30 & 8.51\end{array}\right\} p<0.001$

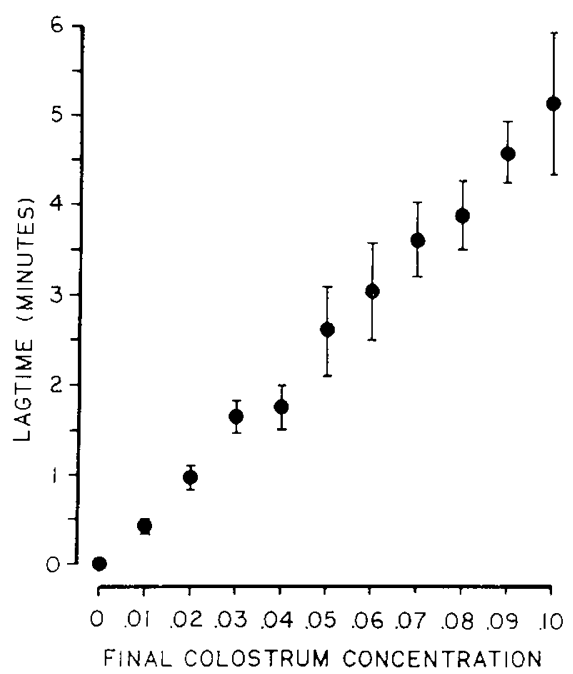

Fig. 4. Dose-response effects of aqueous colostrum on enzymatically produced $\mathrm{H}_{2} \mathrm{O}_{2}$. Final colostrum concentration is shown on the abscissa. Lag time from the addition of glucose oxidase to the appearance of $\mathrm{H}_{2} \mathrm{O}_{2}$ is shown on the ordinate. 
$\mathrm{H}_{2} \mathrm{O}_{2}$ produced by glucose + glucose oxidase were examined (Fig. 5). In two of three specimens tested, colostrum concentrations of $90 \%$ prolonged the lagtime to the appearance of $\mathrm{H}_{2} \mathrm{O}_{2}$ to more than $60 \mathrm{~min}$.

Ten percent aqueous colostrum did not significantly decrease the rate at which $\mathrm{H}_{2} \mathrm{O}_{2}$ was produced by glucose + glucose oxidase $(65.19 \pm 5.76$ versus $54.79 \pm 7.86 \mathrm{nmol} / \mathrm{min}$, control versus $10 \%$ colostrum, $n=10$ and 9 , respectively). Treatment of colostrum with $50 \mathrm{mM}$ aminotriazole (a catalase inhibitor) for $30 \mathrm{~min}$ at $4^{\circ} \mathrm{C}$ decreased $\mathrm{H}_{2} \mathrm{O}_{2}$-depleting activity to $94 \pm 8 \%$ of control ( $n$ $=4)$. In two experiments, treatment of colostrum with $0.05 \%$ sodium azide as an inhibitor of catalase $(30 \mathrm{~min}$, room temperature) decreased its $\mathrm{H}_{2} \mathrm{O}_{2}$ depleting activity to 92 and $93 \%$ of control. Inclusion of catalase into the cell-free $\mathrm{H}_{2} \mathrm{O}_{2}$-generating system did not produce a lag time; rather, it decreased the apparent rate of $\mathrm{H}_{2} \mathrm{O}_{2}$ production. In an experiment not shown, substitution of this $\mathrm{H}_{2} \mathrm{O}_{2}$-producing system for exogenously supplied $\mathrm{H}_{2} \mathrm{O}_{2}$ in the myeloperoxidase assay, with continuous monitoring of myeloperoxidase activity, demonstrated that the suppressive effect of colostrum on myeloperoxidase activity was related to its depleting effect on $\mathrm{H}_{2} \mathrm{O}_{2}$, the substrate for myeloperoxidase. In this system, colostrum caused a delay in the onset of myeloperoxidase activity, but did not affect the rate.

To examine the relationship between the aqueous colostrum element responsible for ferricytochrome $\mathrm{C}$ reduction and the element responsible for depleting $\mathrm{H}_{2} \mathrm{O}_{2}$, the following experiment was performed: colostrum, glucose, and glucose oxidase were combined and the oxidation of scopoletin was monitored fluorometrically. Aliquots of this assay mixture were then removed at different times and examined for ferricytochrome C-reducing activity. Aliquots removed immediately after combining aqueous colostrum, glucose, and glucose oxidase produced initial ferricytochrome $\mathrm{C}$ reduction followed by ferricytochrome $\mathrm{C}$ reoxidation (Fig. 6A). Delay of aliquot removal until after the onset

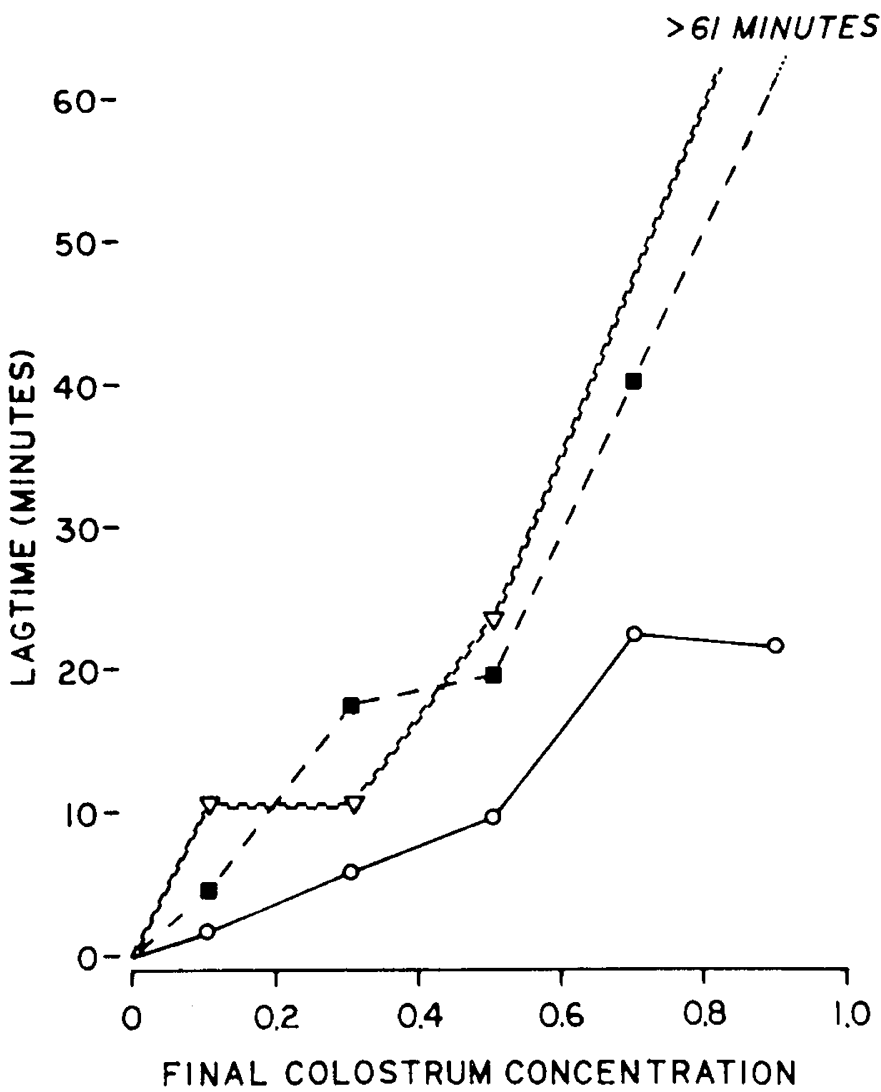

Fig. 5. The effects of increasing human colostrum concentrations on the lag time to the appearance of glucose + glucose oxidase produced $\mathrm{H}_{2} \mathrm{O}_{2}$. Data from three different human colostrum specimens are shown. of scopoletin oxidation (i.e. $\mathrm{H}_{2} \mathrm{O}_{2}$-depleting activity was exhausted) resulted in no ferricytochrome $\mathrm{C}$ reducing activity (Fig. $6 B$ ). Substitution of water for glucose oxidase in the $\mathrm{H}_{2} \mathrm{O}_{2}$ assay resulted in prompt reduction of ferricytochrome $C$ by the aqueous colostrum, which could then be reoxidized by addition of glucose oxidase (Fig. 6, control).

Electrophoretic concentration of colostral activity. Both the cytochrome C-reducing activity and the $\mathrm{H}_{2} \mathrm{O}_{2}$-depleting activity of colostrum could be electrophoretically concentrated: cytochrome C-reducing activity concentrated 4.2 \pm 0.4 -fold $(n=7)$; $\mathrm{H}_{2} \mathrm{O}_{2}$-depleting activity concentrated $5.3 \pm 0.6$-fold $(n=6)$; in three experiments, total colostral protein concentrated $6.9 \pm 2.7$ fold.

\section{DISCUSSION}

It is generally accepted that breast-feeding benefits the newborn infant, providing superior nutrition as well as cellular and humoral elements that might bolster the neonate's host defenses. It has recently been hypothesized that human milk might also be antiinflammatory, based on the paucity of inflammatory mediators it contains, the presence of multiple antiinflammatory components in it, and the depressed functional characteristics of many of the leukocytes it contains (18). Whether this characteristic is real or how it might or might not be beneficial to the infant is currently speculative.

It is known that colostrum, the initial product of lactation, is different from mature milk in its fat composition, protein composition, and the types of leukocytes it contains (19). PMN are the predominant phagocytic cell type in colostrum, whereas in transitional and mature milk, mononuclear phagocytes predominate. The PMN plays a major role in acute inflammation, and the presence of large numbers of PMN in body tissues or fluids (except bone marrow and blood) is synonymous with acute inflammation. The presence of relatively large numbers of PMN in colostrum typically without signs of acute mammary inflammation is somewhat paradoxical. We hypothesized that the PMN present in colostrum are the result of maternal host defense responses to opening up new potential routes of microbial invasion from the environment (i.e. initiating lactation), and that the presence of such activated, exudate PMN would be potentially injurious to the naive, neonatal intestinal epithelium unless their inflammation-inducing capabilities were suppressed. Because the PMN propagates/modulates acute inflammation via its production of oxygen metabolites and secretory products $(1,20)$, we chose to examine the effects of aqueous, acellular colostrum on these aspects of PMN function.

We were unable to examine the effects of colostrum on PMN superoxide production using a standard assay (superoxide dismutase inhibitable ferricytochrome $\mathrm{C}$ reduction) because acellular colostrum spontaneously reduced the cytochrome $\mathrm{C}$ in a rapid, dose-related manner. Interesting facets of this effect were that the reduction was not mediated by an endogenous superoxide generating system (it was not affected by superoxide dismutase), and the reduction did not appear to be enzymatic (the rate rapidly plateaued before complete reduction of the cytochrome C) (Fig. 6, control). We therefore examined the effects of colostrum on $\mathrm{PMN}$ production of $\mathrm{H}_{2} \mathrm{O}_{2}$, the ultimate product of the respiratory burst (21).

Colostrum was found to delay the appearance of PMN-produced $\mathrm{H}_{2} \mathrm{O}_{2}$. The data show that this effect was not mediated by interference with the onset of the PMN respiratory burst per se (colostrum did not cause a lag before the onset of oxygen consumption). Using an enzymatic, acellular system to produce $\mathrm{H}_{2} \mathrm{O}_{2}$, the same effect was seen. In both systems, the major effect of colostrum was to delay the appearance of $\mathrm{H}_{2} \mathrm{O}_{2}$, with little effect on its ultimate rate of appearance (Fig. 2). Such an effect is not likely to be enzymatic, as enzymatic destruction of $\mathrm{H}_{2} \mathrm{O}_{2}$ causes dose-dependent changes in the rate of $\mathrm{H}_{2} \mathrm{O}_{2}$ production in this system. Rather, the colostral component(s) is more likely 


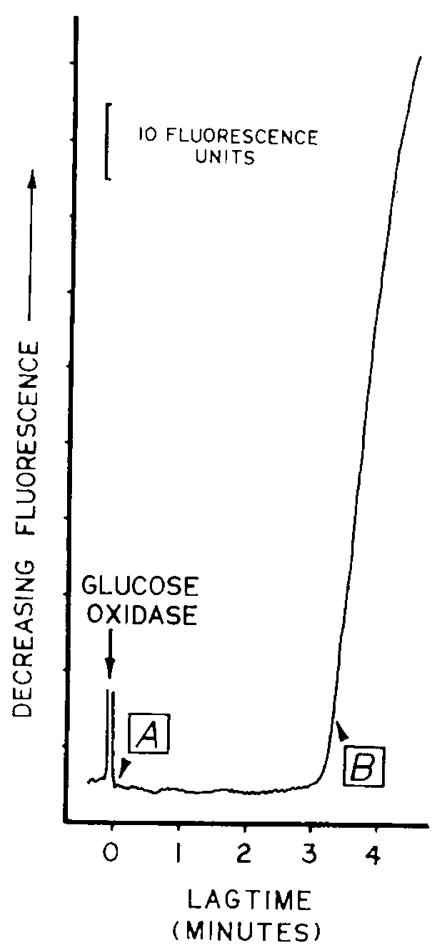

Fig. 6. Effects of exhaustion of colostral $\mathrm{H}_{2} \mathrm{O}_{2}$ depleting activity on colostral cytochrome $\mathrm{C}$ reducing activity. Left, tracing of scopoletin oxidation (glucose + glucose oxidase produced $\mathrm{H}_{2} \mathrm{O}_{2}$ ) in the presence of 0.10 aqueous colostrum. $A$ and $B$ show times at which aliquots were removed from parallel experiments and assayed for ferricytochrome $\mathrm{C}$ reducing activity. Right (top), spontaneous ferricytochrome $\mathrm{C}$ reducing

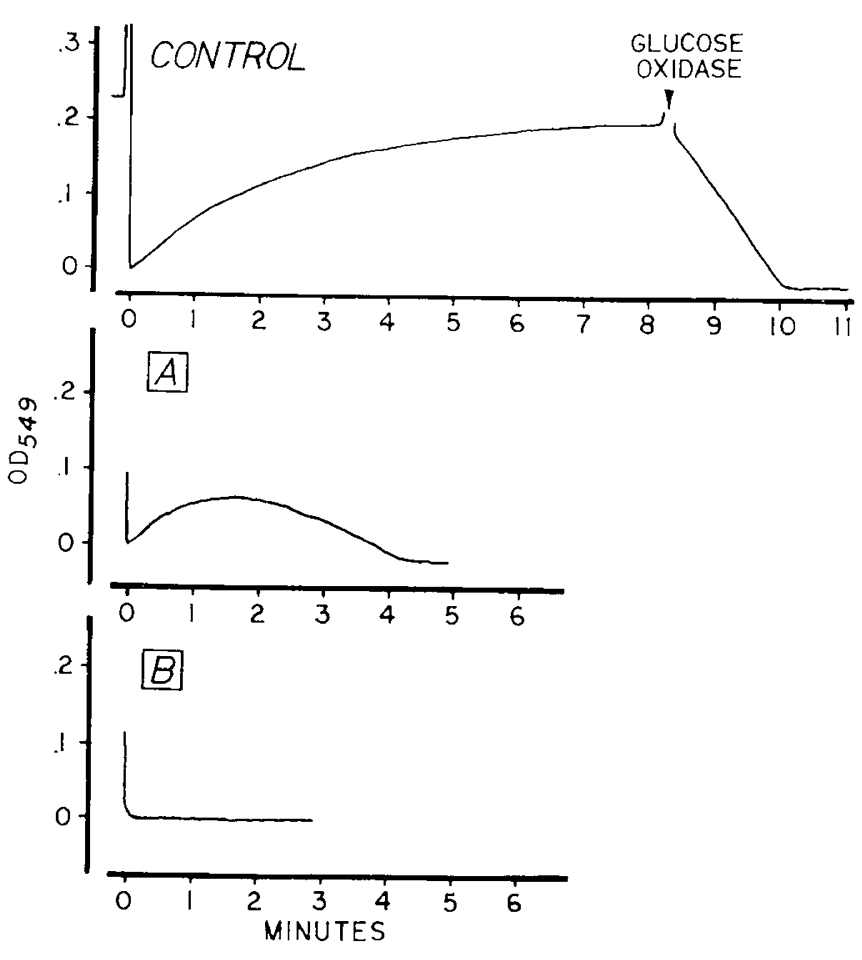

activity of aqueous colostrum. OD549 is shown on the ordinate; time in min is shown on the abscissa. Arrow shows time of addition of glucose oxidase. (Middle), spontaneous ferricytochrome $\mathrm{C}$ reduction by an aliquot removed at time point $A$ (bottom), spontaneous ferricytochrome C reduction by an aliquot removed at time point $B$.

tempting to speculate that such a sparing effect might help protect the neonatal intestine from potentially injurious maternal PMN that are present in the colostrum.

These studies do not chemically identify the colostral component(s) that mediate its antioxidant activity. The concentration of the antioxidant activity at the surface of a $3.5-\mathrm{kDa}$ dialysis membrane at $\mathrm{pH} 8$ suggests the component(s) is larger than 3.5 $\mathrm{kDa}$ and that it carries a positive charge at $\mathrm{pH} 8$. In a single experiment (data not shown) using $\mathrm{pH} 5$ buffer for electrocentration, the antioxidant activity did not concentrate, suggesting that the component(s) is either uncharged or unstable at that $\mathrm{pH}$. A number of small antioxidant compounds are reported to be present in human colostrum: ascorbate is present in concentrations of $47-104 \mathrm{mg} /$ liter $(267-591 \mathrm{nmol} / \mathrm{ml})$ in cellular, whole colostrum (22); cystine and taurine are present in acellular, aqueous colostrum at concentrations of $25 \pm 9$ and $413 \pm 71$ $\mathrm{nmol} / \mathrm{ml}(23) ; \alpha$-tocopherol is present in cellular, whole colostrum at a concentration of about $23 \mathrm{nmol} / \mathrm{ml}(24)$. Studies examining the possible roles of each of these components in colostral antioxidant activity are currently underway.

These studies are the first to show that human colostrum creates a chemically reducing environment in which PMN-produced $\mathrm{H}_{2} \mathrm{O}_{2}$ is not available as an oxidant or a substrate for other PMN enzymatic systems. They also show that colostrum can protect against PMN-mediated cellular injury. Taken together, they support the concept that colostrum is antiinflammatory.

\section{REFERENCES} Because colostrum would exert its effects at the level of the mucosal surface in the intestine, this cell line was considered more appropriate for examining PMN effects than classically used vascular endothelium. As might be anticipated, PMAstimulated PMN caused significant detachment of HEp-2 cells; $10 \%$ whole colostrum significantly ameliorated this PMN-mediated effect, consistent with its antioxidant capabilities. It is
1. Weissmann G, Smolen JE, Korchak HM 1980 Release of inflammatory mediators from stimulated neutrophils. N Engl J Med 303:27-34 proteinases and cationic proteins. J Clin Invest 79:669-674

3. Gallin JI, Buescher ES 1983 Abnormal regulation of inflammatory skin re$7: 227-232$
2. Henson PM, Johnston RB 1987 Tissue injury in inflammation. Oxidants, sponses in male patients with chronic granulomatous disease. Inflammation 
4. Pickering LK, Cleary TG, Kohl S, Getz S 1980 Polymorphonuclear leukocytes of human colostrum. I. Oxidative metabolism and kinetics of killing of radiolabeled Staphylococcus aureus. J Infect Dis 142:685-693

5. Khan AJ, Rosenfeld W, Vadapalli M, Biagton M, Khan P, Afroza H, Evans HE 1980 Chemotaxis and random migration of human milk cells. J Pediatr 96:879-882

6. Boyüm A 1968 Isolation of mononuclear cells and granulocytes from human blood. Isolation of mononuclear cells by one centrifigation and of granulocytes by combining centrifugation and sedimentation at $1 \mathrm{~g}$. Scand $\mathbf{J}$ Clin Lab Invest 21(suppl 97):77-89

7. Root RK, Stossel TP 1974 Myeloperoxidase-mediated iodination by granulocytes. Intracellular site of operation and some regulating factors. J Clin Invest 53:1207-1215

8. Root RK, Metcalf J, Oshino N, Chance B $1975 \mathrm{H}_{2} \mathrm{O}_{2}$ release from human granulocytes during phagocytosis. I. Documentation, quantitation and some regulating factors. J Clin Invest 55:945-955

9. Henson PM, Zanolari B, Schwartzman NA, Hong SR 1978 Intracellular control of human neutrophil secretion. I. C5a-induced stimulus-specific desensitization and the effects of cytochalasin B. J Immunol 121:851-855

10. Smolelis AN, Hartsell SE 1949 The determination of lysozyme. J Bacteriol 58:731-736

11. Talalay P, Fishman WH, Huggins C 1946 Chromogenic substrates II. Phenolphthalein gluceronic acid as substrate for the assay of glucuronidase activity. J Biol Chem 166:757-772

12. Hay R, Macy M, Corman-Weinblatt A, Chen TR, McClintock P (eds) Catalog of Cell Lines and Hybridomas, 5th ed. 1985 American Type Culture Collection, Rockville, MD, p 15

13. Cravioto A, Gross RJ, Scotland SM, Rowe B 1979 An adhesive factor found in strains of Escherichia coli belonging to the traditional enteropathogenic serotypes. Curr Microbiol 3:95-99
14. Mathewson JJ, Johnson PC, DuPont HL, Morgan DR, Thornton SA, Wood LV, Ericsson CD 1985 A newly recognized cause of travelers' diarrhea: enteroadherent Escherichia coli. J Infect Dis 151:471-475

15. Lowry OH, Rosebrough NJ, Farr AL, Randall RJ 1951 Protein determination with the folin phenol reagent. J Biol Chem 193:265-275

16. Absolom D 1986 Basic methods for the study of phagocytosis. In: Colowick SP, Kaplan NO (eds) Methods in Enzymology, vol 32. Academic Press, Orlando, FL, p 151

17. Hunkapillar MW, Lujan E, Ostander F, Hood LE 1983 Isolation of microgram quantities of proteins from polyacrylamide gels for amino acid sequence analysis. In: Hirs CHW, Timasheff SN (eds) Methods in Enzymology, vol 91. Academic Press, New York, pp 689-695

18. Goldman AS, Thorpe LW, Goldblum RM, Hanson LA 1986 Anti-inflammatory properties of human milk. Acta Pediatr Scand 75:689-695

19. Adcock EW, Brewer ED, Caprioli RM, West MS 1986 Macronutrients electrolytes and minerals in human milk: differences over time and between population groups. In: Howell RR, Morriss FH, Pickering LK (eds) Human Milk in Infant Nutrition and Health. Charles C Thomas, Springfield, IL pp 3-27

20. Fantone JC, Ward PA 1985 Polymorphonuclear leukocyte-mediated cell and tissue injury. Oxygen metabolites and their relations to human disease. Hum Pathol 16:973-978

21. Klebanoff SJ 1980 Oxygen metabolism and the toxic properties of phagocytes. Ann Intern Med 93:480-489

22. Macy IG 1949 Composition of human colostrum and milk. Am J Dis Child 78:589-603

23. Rassin DK, Sturman JA, Gaull GE 1978 Taurine and other free amino acids in milk of man and other mammals. Early Hum Dev 2:1-13

24. Jansson L, Akesson B, Holmberg L 1981 Vitamin E and fatty acid composition of human milk. Am J Clin Nutr 34:8-13 